\title{
Synthesis of 2-Pyridone from 2-Thiopyridines via Nu- cleophilic Aromatic Substitution Reaction
}

\author{
Digvijaysinh K. Parmar*† and Hardik B. Bhatt *
}

†Diu College, DHES, Diu (U.T.)- 362520, India. ¥Om College of Science, Junagadh-Gujrat-362310, India.

\begin{abstract}
2-Thiopyridine has been used for the synthesis of 2-pyridones. Aromatic nucleophilic substitution reaction has been utilized for the transformation of 2-pyridine into 2-pyridones. Reusability of the released dithiol into generation of 2thiopyridine explores reactivity of thiol as a template in synthesis of pyridine core. The present method explores making 2-pyridone derivatives utilizing 2-thiopyridines whereas thiol act as a template for pyridine synthesis.
\end{abstract}

Keywords: 2-Thiopyridine, 2-Pyridone, $\mathrm{S}_{\mathrm{NA}} \mathrm{Ar}$ DMSO, $\mathrm{NaOH}$

\section{Introduction}

The 2-pyridone tautomer of 2-hydroxypyridine is one of the important moiety in many biologically active compounds (1). Although 2-pyridones are not documented as vast natural sources but those which are isolated shows potent cytotoxicity (2). Natural as well as unnatural 2-pyridones possesses a wide range of biological activities such as antitumor (3), antifungal (4), antibacterial (5), antiinflammatory (6), antiviral (7) and antithrombotic (8) properties. Majority of the 2-pyridones are synthetic molecules and are found in pharmaceutical products some of which are as Topotecan and Irinotecan. Derivatives of 2-pyridones have also been investigated for their important applications in dyes, sensors, pigments and advanced materials, carriers of singlet oxygen and as catalysts (9). It has received considerable attention due to its promising features as a key scaffold and in privileged building blocks (10). Among various 2-pyridone molecules some marketed cyanotethered drugs such as Milrinone (11) and Olprinone (12) are well-known to use in patients for the treatment with heart related problems. Simi- larly, Ricinine (13) another types of cyanotethered 2-pyridones that serves as a biomarker and INDOPY-1 (14) in dolopyridones strucan ture a potential inhibitor of human immunodeficiency virus. Recently, 3-cyano-pyridone of type (A) has been reported as antibacterial and antitubercular activities (15). The explored applications of 2pyridones currently attracted attentions of synthetic and medicinal chemists for their further developments and can be found from recently published reviews and articles (16).

To quick access derivatives of 2pyridones generally and most preferably synthetic strategy adopted are nucleophilic aromatic substitution reactions $\left(\mathrm{S}_{\mathrm{N}} \mathrm{Ar}\right)$. This potential method

\footnotetext{
*Address of Correspondence: Dr. Digvijaysinh K. Parmar, Assistant Professor, Department of Chemistry, Diu College, DHES, Diu (U.T)- 362520, India. E-mail: pdsinh7@gmail.com (Received 30 December 2019; revised 12 January 2020; accepted 16 January 2020).
} 
<smiles>Cc1[nH]c(=O)c(C#N)cc1-c1ccncc1</smiles>

1. Milrinone<smiles>Cn1c2ccccc2c2c1cc(C#N)c(=O)n2-c1ccc([N+](=O)[O-])cc1</smiles><smiles>COc1ccn(C)c(=O)c1C#N</smiles>

2. Ricinine<smiles>Cc1c(-c2ccc3nccn3c2)cc(C#N)c(=O)n1C</smiles>

Olprinone-Market drugs

Figure 1: Important 2-pyridone drugs and bioactive molecules

$\mathrm{S}_{\mathrm{N}} \mathrm{Ar}$ has become an ideal synthetic tool to obtain 2-pyridone heterocycles from starting 2substituted pyridines (17).

The major class of transformations takes place displacement of halogens/amino groups by nucleophiles at position C-2 of the pyridine moiety (18). These reactions are versatile for the functionalization in pyridines but requires drastic reaction conditions, often leads to mixtures and low yields of product. The other class includes additions of nucleophiles to pyridine $\mathrm{N}$-oxides in combination with a reagent to activate and dehydrate the pyridine $\mathrm{N}$-oxide (19) (Scheme 1). Herein, to the best of our knowledge work in this manuscript is novel and explores nucleophilic aromatic displacement reaction of labile thiol in synthesis of 2-pyridones.

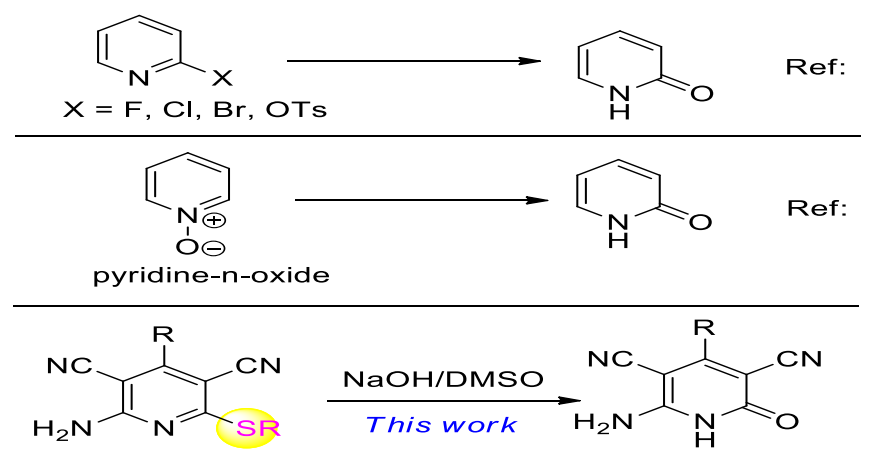

Scheme 1: Nucleophilic aromatic substitution strategies for the functionalization of pyridines to 2-Pyrodones

To the previously reported experiments (20) it was observed that synthesizing 2-thiopyridine (1) was not achievable in strong Bronsted base and was also reported in the literature (21). From this previous experimental studies we found that formation of thiol moiety at C-2 of pyridine was easily in situ replaced by alkoxy group just after the formation of thiopyridine. That's why thiopyridine was never obtained in presence of concentrated Bronsted base and always final product was ended-up with alkoxy pyridine. Basically, the idea emerged from this model 
experiment that thiopyridine could be transformed to 2-pyridones. Direct synthesis of 2Pyridones similar to structure 2 had been reported using reactions of aldehydes and malononitrile in presence of base and water but yields obtained were very low in amount and excess amount of malononitrile and aldehydes were sacrificed (22).

The important features of this method is that after the formation of 2-pyridones it forms by-product dimer of thiophenol. This dimer can be reduced to thiophenol (23) and can be reused again for the synthesis of thiopyridines and will follow a cyclic process. To our surprise it is interesting to note that here thiol act as a template for the synthesis of pyridine, which can be transformed to another important privileged molecules 2-thiopyridones. We are continuing our research in the same direction to explore transformation of one molecule to another using thiol as a template.

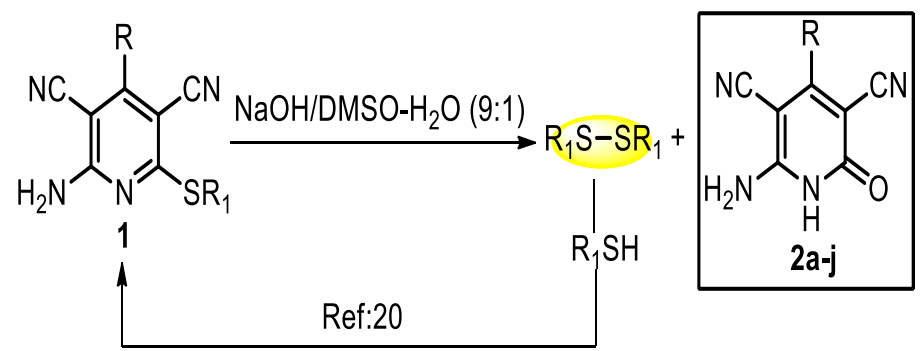

Scheme 2: Synthesis of 2-pyridone from 2-thiopyridine

\section{Experimental Methods}

All the reagents were used without further purification and were procured from commercial sources. The reactions were performed under the normal atmosphere condition. The progress of the reaction and purity of the compound were monitored using the thin layer chromatography (TLC) carried out on the silica gel with UV light and iodine as visualizing agent. A Shimadzu FT-IR-8400 spectrophotometer was used for recording the IR spectra. ${ }^{1} \mathrm{H}$ NMR and ${ }^{13} \mathrm{C}$ NMR spectra were recorded using the Bruker advance-III $400 \mathrm{MHz}$ spectrometers in DMSO- $\mathrm{d}_{6}$ using TMS as an internal reference. The chemical shift ( $\delta$ scale) was reported in parts per million (ppm). Elemental analysis was carried out using a Euro Vector EA3000 CHNS-O analyser at NFDD Saurashtra University, Rajkot, Gujarat.

\section{General procedure for the synthesis of compound 2 (GP1)}

A mixture of 2-thiopyridine $(1.0 \mathrm{mmol}), \mathrm{NaOH}$ $(1.0 \mathrm{mmol})$ and DMSO $+\mathrm{H}_{2} \mathrm{O}(8: 2 ; 5.0 \mathrm{~mL})$ mixture was heated at $60{ }^{\circ} \mathrm{C}$ at appropriate time for complete the reaction and was monitored on TLC us- ing $\mathrm{CHCl}_{3}: \mathrm{MeOH}$; 9:1. After completion of the reaction, reaction mass was cooled to room temperature. Added $5.0 \mathrm{~mL}$ water and the reaction mass was filtered. The clear filtrate was adjusted with $1 \mathrm{~N} \mathrm{HCl}$ to form the precipitates at acidic condition. The precipitate was filtered and washed with fresh water $10 \mathrm{~mL}$ twice and air dried. The obtained solid was pure enough for further characterization.

The spectroscopic data for 6-amino-2-oxo-4phenyl-1,2-dihydropyridine-3,5-dicarbonitrile (2a). This compound was obtained according to above general procedure GP1; IR (potassium bromide): 3460, 3311, 3110, 2218, 1675, 1635, 1540, 1486, 1440, 1266, 1043, 874, 718, $649 \mathrm{~cm}^{-1}$; ${ }^{1} \mathrm{H}$ NMR (DMSO- $\mathrm{d}_{6}$ ): $\delta=11.90(\mathrm{~s}, 1 \mathrm{H}, \mathrm{NH}), 7.81$ (brs, 2H, $\mathrm{NH}_{2}$ ), 7.56-7.52 (m, 3H, ArH), 7.50-7.47 (m, 2H, ArH); Anal. Calcd. for $\mathrm{C}_{13} \mathrm{H}_{8} \mathrm{~N}_{4} \mathrm{O}: \mathrm{C}, 66.10$; H, 3.41; N, 23.72. Found: C, 66.03; H, 3.38; N, 23.66 . 


\section{Results and Discussion}

In our initial study of thiopyridine 2-amino-4phenyl-6-(phenylthio)pyridine-3,5-dicarbonitrile (1.0 mmol) was stirred at room temperature for $24 \mathrm{~h}$ in distilled water to react with it but no any trace for $\mathbf{2 a}$ was observed (Table 1, entry 1). Same reaction combinations were heated to reflux but no any changes were observed (Table 1, entry 2). This was attributed as substrate was insoluble in

In another experiment $\mathrm{NaOH}$ was added to DMSO alone and was heated at $100{ }^{\circ} \mathrm{C}$, surprisingly $62 \%$ yield was obtained in $3 \mathrm{~h}$ (Table 1 , entry $5)$. Progress of the reaction can be easily monitored on TLC $\left(\mathrm{CHCl}_{3}: \mathrm{MeOH} ; 9: 1\right)$ and also can be traced by smelling like thiophenol of the reaction mass. As the reaction proceed towards $\mathbf{2 a}$, smell become stronger. To this same reaction model solvent mixture of DMSO and water was taken into 8:2 ratio along with $\mathrm{NaOH}$ and was heated again at $100{ }^{\circ} \mathrm{C}$, yield was increased to $88 \%$ and also reduces the reaction time (Table 1 , entry 6). This may be due to the solubilizing factor of the starting substrate and $\mathrm{NaOH}$ in the solvent mixture. To check the effect of temperature on yield, the same reaction combinations was heated at 60 ${ }^{\circ} \mathrm{C}$ instead of $100{ }^{\circ} \mathrm{C}$, yield obtained was $97 \%$ in $2 \mathrm{~h}$ (Table 1, entry 7). Looking towards mild reaction conditions the reaction was performed at room water. In another attempt DMSO (5.0 mL) as a solvent was taken and added water (1.0 equiv.) with the same starting substrate and heated at $100{ }^{\circ} \mathrm{C}$ but this time also no any changes were observed (Table 1, entry 3 ). Next, $\mathrm{NaOH}$ (1.0 eqv.) was added to water and stirred at reflux temperature for $24 \mathrm{~h}$ but only trace amount for $\mathbf{2 a}$ was observed because of solubility problem of thiopyridine in water (Table1, entry 4).

temperature, after $15 \mathrm{~h}$ long reaction time only $58 \%$ yield was observed (Table 1, entry 8). Next, impact of solvent combinations of DMSO and water (Table 1, entries 9-10) was also checked but were not significant compare to the DMSO and water ratio 8:2. Similarly, other Bronsted bases such as $\mathrm{KOH}, \mathrm{LiOH}, \mathrm{Mg}(\mathrm{OH})_{2}$ and $\left.\mathrm{CaOH}\right)_{2}$ were screened but results were not encouraging other than $\mathrm{KOH}$ (Table 1, entries 11-14). Finally, the same reaction combinations was heated at $60{ }^{\circ} \mathrm{C}$ in presence of $\mathrm{HCl}$ as a Bronsted acid but yield was extremely low with long reaction time (Table1, entry 15). Alcoholic solvents such as methanol or ethanol were not included as they form the alkoxy-thiopyridines. Due to solubility problems of the starting substrates thiopyridines in solvent such as toluene and dichloromethane and the formation of dichlorocarbene with chloroform and $\mathrm{NaOH}$ these solvents were not suitable in this transformation.

Table 1: Optimization of reaction conditions ${ }^{\mathrm{a}}$<smiles>N#Cc1c(N)[nH]c(=O)c(C#N)c1-c1ccccc1</smiles> 


\begin{tabular}{|c|c|c|c|c|c|}
\hline Entry & $\begin{array}{l}\text { Reagent }(1.0 \\
\text { eqv. })\end{array}$ & Solvent & Temp. ( $\left.{ }^{\circ} \mathrm{C}\right)$ & Time & Yieldb (\%) $^{b}$ \\
\hline 1 & --- & $\mathrm{H}_{2} \mathrm{O}$ & $\mathrm{rt}$ & $24 \mathrm{~h}$ & nil \\
\hline 2 & --- & $\mathrm{H}_{2} \mathrm{O}$ & reflux & $24 \mathrm{~h}$ & nil \\
\hline 3 & $\mathrm{H}_{2} \mathrm{O}$ & DMSO & 100 & $24 \mathrm{~h}$ & nil \\
\hline 4 & $\mathrm{NaOH}$ & $\mathrm{H}_{2} \mathrm{O}$ & reflux & $24 \mathrm{~h}$ & trace \\
\hline 5 & $\mathrm{NaOH}$ & DMSO & 100 & $3.0 \mathrm{~h}$ & 62 \\
\hline 6 & $\mathrm{NaOH}$ & DMSO- $\mathrm{H}_{2} \mathrm{O}(8: 2)$ & 100 & $1.5 \mathrm{~h}$ & 88 \\
\hline 7 & $\mathrm{NaOH}$ & DMSO-H ${ }_{2} \mathrm{O}(8: 2)$ & 60 & $2.0 \mathrm{~h}$ & 97 \\
\hline 8 & $\mathrm{NaOH}$ & DMSO- $\mathrm{H}_{2} \mathrm{O}(8: 2)$ & $\mathrm{rt}$ & $15 \mathrm{~h}$ & 58 \\
\hline 9 & $\mathrm{NaOH}$ & DMSO- $\mathrm{H}_{2} \mathrm{O}(1: 1)$ & 60 & $5.0 \mathrm{~h}$ & 80 \\
\hline 10 & $\mathrm{NaOH}$ & DMSO- $\mathrm{H}_{2} \mathrm{O}(9.5: .5)$ & 60 & $3.0 \mathrm{~h}$ & 86 \\
\hline 11 & $\mathrm{KOH}$ & DMSO- $\mathrm{H}_{2} \mathrm{O}(8: 2)$ & 60 & $1.5 \mathrm{~h}$ & 92 \\
\hline 12 & $\mathrm{LiOH}$ & DMSO- $\mathrm{H}_{2} \mathrm{O}(8: 2)$ & 60 & $3.0 \mathrm{~h}$ & 83 \\
\hline 13 & $\mathrm{Mg}(\mathrm{OH})_{2}$ & DMSO-water (8:2) & 60 & $3.5 \mathrm{~h}$ & 70 \\
\hline 14 & $\mathrm{Ca}(\mathrm{OH})_{2}$ & DMSO-water (8:2) & 60 & $3 \mathrm{~h}$ & 72 \\
\hline 15 & $\mathrm{HCl}$ & DMSO-water (8:2) & 60 & $10 \mathrm{~h}$ & 15 \\
\hline
\end{tabular}

aReaction of 2-amino-4-phenyl-6-(phenylthio)pyridine-3,5-dicarbonitrile $(1.0 \mathrm{mmol})$ at different reaction conditions; bIsolated yields.

With the optimized conditions in hand we turned our attention to explore the scope and general applicability of this process by carrying out the synthesis of 2-pyridones using different thio-pyridines (Table 2). Thio-pyridine derivatives with varying electron donating/withdrawing functionality in the aromatic ring were tested and were found to be suitable in this reaction (Table 2, $2 \mathrm{~b}-2 \mathrm{k}$ ) in good yields. Highest yields were observed for $\mathrm{N}$-protected isatin derivatives and in case of nitro derivative lower yield was observed among all the synthesized spirooxindole molecules. These synthesized molecules were confirmed from IR spectra and melting point reported in the literature. ${ }^{1} \mathrm{H}$ NMR and ${ }^{13} \mathrm{C}$ NMR spectra for one of the compound $\mathbf{4 a}$ are provided in Fig. 2 and Fig. 3 respectively. To check the feasibility of this developed process, a scale-up reaction was performed under the optimized reaction condition to obtain $4 \mathbf{a}$ by taking isatin $(10 \mathrm{mmol})$, malononitrile (10 mmol) and 4-hydroxycoumarin (10 mmol) and the yield obtained was $97 \%$.

Finally, a comparison was made between the present reaction process and many other earlier reported protocols for the synthesis of $\mathbf{4 a}$ as a model compound. The results summarized in Table 3 evident that the process developed by us is superior to most of the earlier reported methods in terms of operational simplicity, yields, reaction time, cost, easy availability, reusability and environmental compatibility. 
Table 2: Substrates Scope ${ }^{a}$<smiles>[R]c1c(C#N)c(N)nc(-c2ccccc2)c1C#N</smiles><smiles>[R]c1c(C#N)c(N)[nH]c(=O)c1C#N</smiles>

$2 a-2 n$

$\mathrm{R}=$ alkyl/aryl

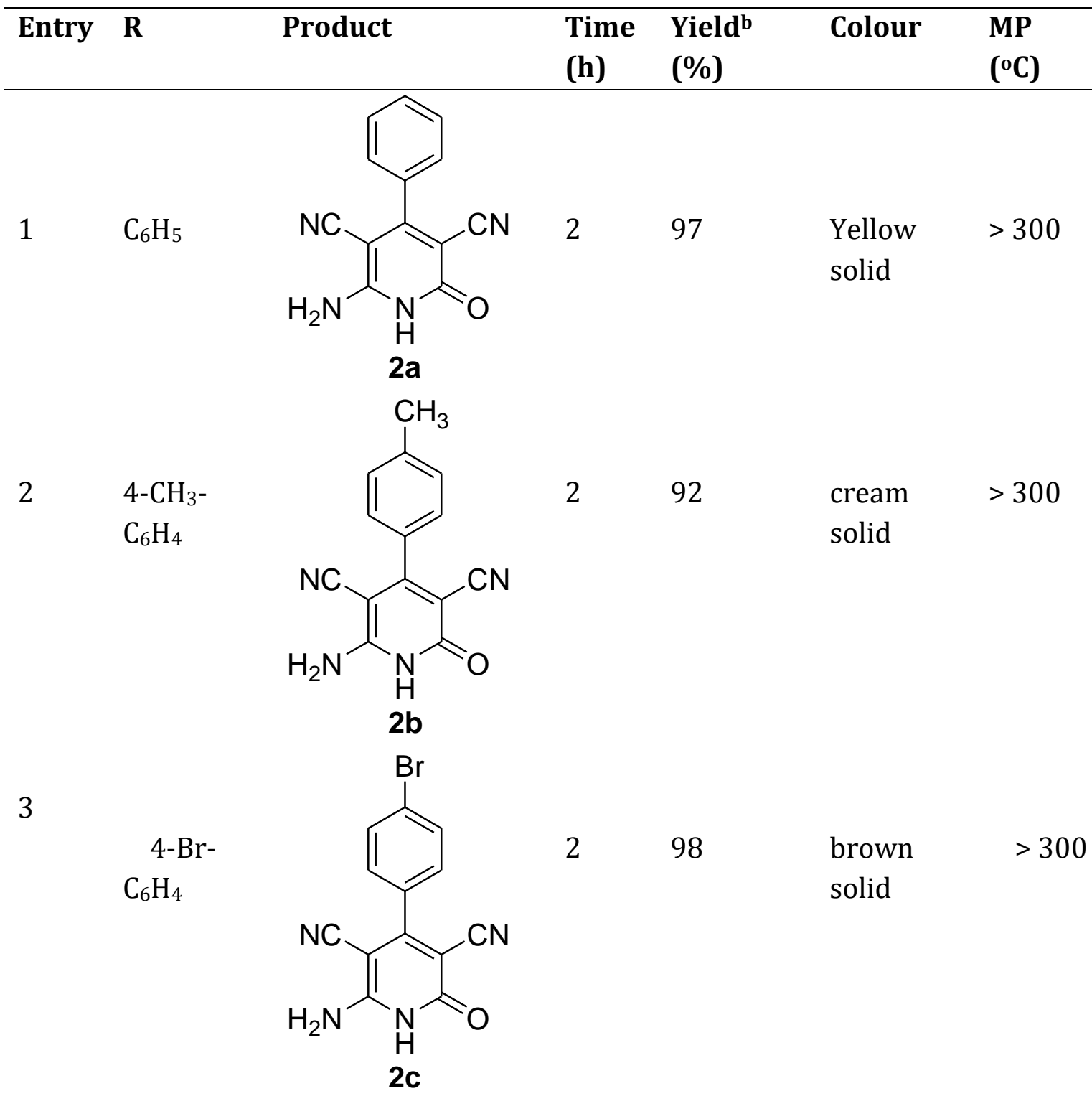




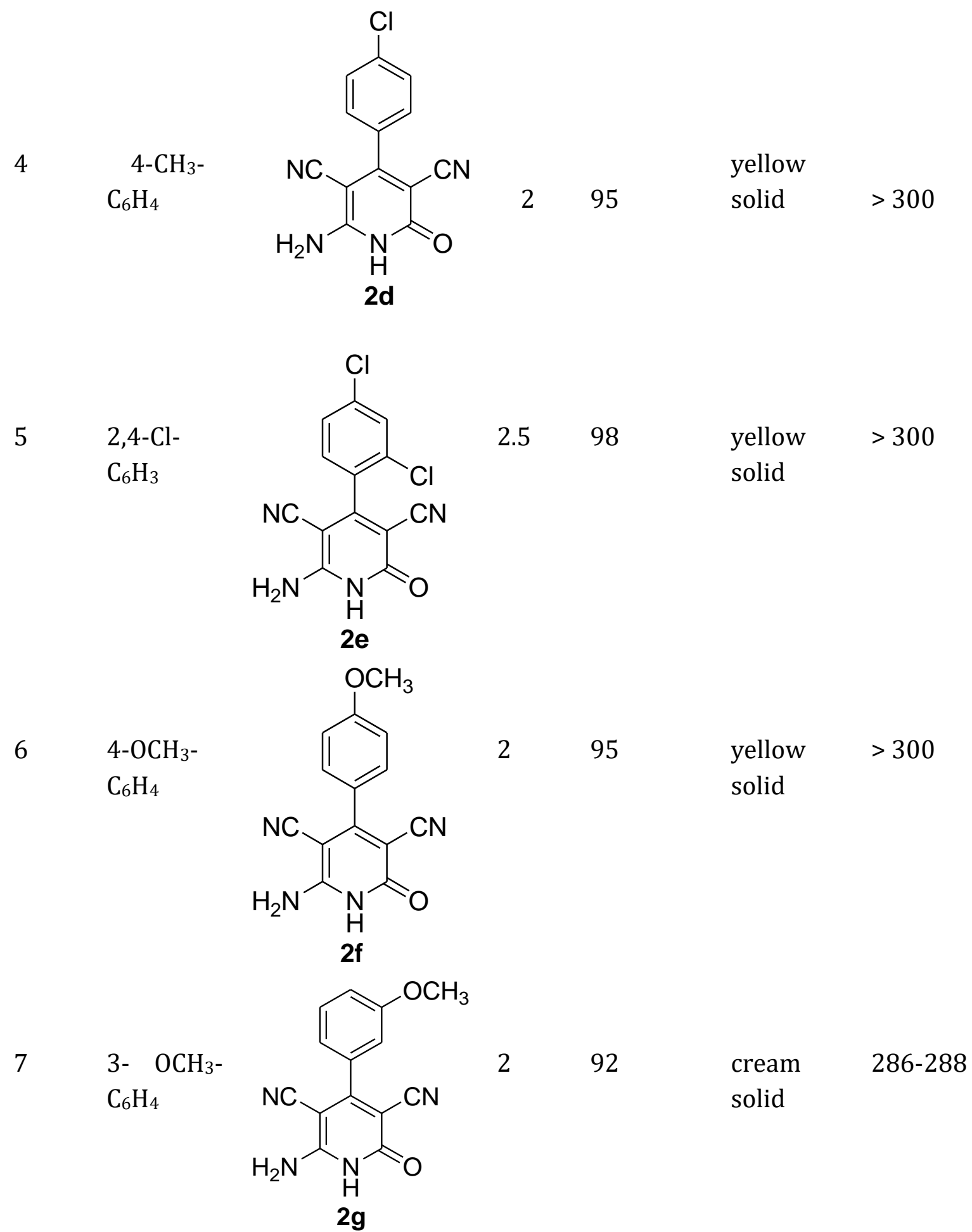


8
3,4-
$\mathrm{OCH}_{3}-$
$\mathrm{C}_{6} \mathrm{H}_{3}$<smiles>COc1ccc(-c2c(C#N)c(N)[nH]c(=O)c2C#N)cc1OC</smiles>

3<smiles>N#Cc1c(N)[nH]c(=O)c(C#N)c1-c1cccc(Oc2ccccc2)c1</smiles>

2.5 $\mathrm{C}_{6} \mathrm{H}_{4}$

10

$$
\begin{aligned}
& \text { 4-OH- } \\
& \mathrm{C}_{6} \mathrm{H}_{4}
\end{aligned}
$$

11
$\mathrm{C}_{6} \mathrm{H}_{11}$<smiles>N#Cc1c(N)[nH]c(=O)c(C#N)c1C1CCCCC1</smiles>

$2.5 \quad 98$

cream $>300$ cream $>300$

solid brown $>300$

solid<smiles>Cc1c(C#N)c(N)[nH]c(=O)c1C#N</smiles>

2j

19 
<smiles>N#Cc1c(N)[nH]c(=O)c(C#N)c1Cc1ccccc1</smiles>

solid<smiles>N#Cc1c(N)[nH]c(=O)c(C#N)c1-c1ccc2ccccc2c1</smiles>

2-

thiophen

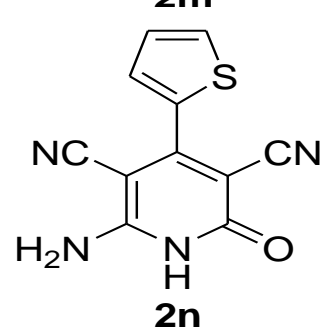

solid

2

94

brown $\quad>300$
solid

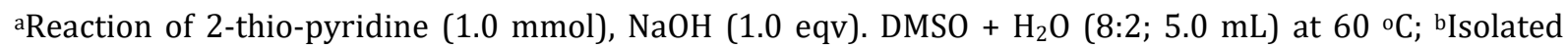
yields.

\section{Conclusions}

In summary, the present work describes a simple and facile method for the synthesis of highly functionalized 3-cyano-2-pyridone from simple starting substrate. This novel method explored the use of thiol template synthesis of 2-pyridone. The use of formed dithiol in cyclic reaction makes the process an economical. This new methodology can be useful strategy to explore synthesis of making different organic molecules.

\section{Acknowledgement}

Authors are grateful to Diu College for providing basic research facilities to carry out this work.

Authors are also grateful to the CoE. NFDD, Saurashtra University, Rajkot-Gujarat for IR, NMR and CHN analysis of the synthesized molecules.

\section{Disclosure}

The authors report no conflicts of interest in this work. No violation of human rights and safety.

\section{References}

1. (a). Li $Q$, Mitscher LA, Shen LL. The 2-pyridone antibacterial agents: bacterial topoisomerase inhibitors. Med Res Rev. 2000; 20: 231-293. (b). Jessen HJ, Gademann K. K. 4-Hydroxy-2-pyridone alkaloids: Structures and synthetic approaches. Nat Prod Rep. 2010; 27: 1168-1185. (c). Vite-Caritino H, MendezLucio O, Reyes H, Cabrera A, Chavez D. MedinaFranco JL. Advances in the development of pyridinone derivatives as non-nucleoside reverse transcriptase inhibitors. RSC Adv. 2016; 6: 2119-2130.

2. (a). Andrioli WJ, Lopes AA, Cavalcanti BC, Pessoa C, Nanayakkara NPD, Bastos JK. Isolation and characterization of 2-pyridone alkaloids and alloxazines from Beauveria bassiana. Nat Prod Res. 2017; 31: 19201929. (b). Chicca A, Berg R, Jessen HJ, Marck N, 
Schmid F, Burch P, Gertsch J, Gademann K. Biological evaluation of pyridone alkaloids on the endocannabinoid system. Bioorg Med Chem. 2017; 25: 61026114. (c). Haga A, Tamoto $H$, Ishino M, Kimura $E$, Sugita T, Kinoshita K, Takahashi K, Shiro M, Koyama K. Pyridone Alkaloids from a Marine-Derived Fungus, Stagonosporopsis cucurbitacearum, and Their Activities against Azole-Resistant Candida albicans. J. Nat Prod. 2013; 76: 750-754. (d). Peng X, Wang Y, Sun K, Liu P, Yin X, Zhu W Cerebrosides and 2-Pyridone Alkaloids from the Halotolerant Fungus Penicillium chrysogenum Grown in a Hypersaline Medium. J. Nat Prod. 2011; 74: 1298-1302.

3. Hasvold LA, Wang W, Gwaltney SL, Rockway TW, Nelson LTJ, Mantei RA, Fakhoury SA, Sullivan GM, Li Q, Lin $\mathrm{NH}$, Wang L, Zhang H, Cohen J, Gu WZ, Marsh K, Bauch J, Rosenberg S, Sham HL. Pyridone-Containing farnesyltransferase inhibitors: synthesis and biological evaluation. Bioorg Med Chem Lett. 2003; 13: 400105 .

4. Cox RJ, O'Hagan D. Synthesis of isotopically labelled 3amino-2-phenylpropionic acid and its role as a precursor in the biosynthesis of tenellin and tropic acid. J. Chem Soc Perkin Trans. 1991; 1: 2537-2540.

5. (a) Li Q, Mitscher LA, Shen LL. The 2-pyridone antibacterial agents: bacterial topoisomerase inhibitors. Med Res Rev. 2000; 20: 231-293. (b) Fujita Y, Oguri H, Oikawa H. Biosynthetic studies on the antibiotics PF1140: a novel pathway for a 2-pyridone framework. Tetrahedron Lett. 2005; 46: 5885- 5888.

6. Semple G, Andersson BM, Chhajlani V, Georgsson J, Johansson MJ, Rosenquist A, Swanson L. Synthesis and Biological activity of kappa opioid receptor agonists. Part 2: Preparation of 3-aryl-2-pyridone analogues generated by solution- and solid-phase parallel synthesis methods. Bioorg Med Chem Lett. 2003; 13: 1141- 1145.

7. Lv Z, Sheng C, Wang T, Zhang Y, Liu J, Feng J, Sun H, Zhong H, Niu C, Li K. Design, Synthesis, and Antihepa- titis B Virus Activities of Novel 2-Pyridone Derivatives. J. Med Chem. 2010; 53: 660-668.

8. Parlow JJ, Kurumbail RG, Stegeman RA, Stevens AM, Stallings WC, South MS. Design, Synthesis, and Crystal Structure of Selective 2-Pyridone Tissue Factor VIla Inhibitors. J. Med Chem. 2003; 46: 4696-4701.

9. (a). Callaghan S, Filatov MA, Sitte E, Savoie H, Boyle RW, Flanagana KJ, Senge MO. Delayed release singlet oxygen sensitizers based on pyridone-appended porphyrins. Photochem Photobiol Sci. 2017; 16: 13711374. (b). Maezono SMB, Poudel TN, Xia L, Lee YR. A green synthetic approach to synthesizing diverse 2pyridones for their exceptional UV shielding functions. RSC Adv. 2016; 6: 82321-82329. (c). Kasprzyk W, Krzywda P, Bednarz S, Bogdał DV. Fluorescent citric acid-modified silicone materials. RSC Adv. 2015; 5: 90473-90477. (d). You Y. Chemical tools for the generation and detection of singlet oxygen. Org Biomol Chem. 2018; 16: 4044-4060. (e). Ren C, Shen J, Zeng $\mathrm{H}$. One-Pot Synthesis of Strained Macrocyclic Pyridone Hexamers and Their High Selectivity toward Cu2+ Recognition. Org Lett. 2015; 17: 5946-5949.

10. (a). Kulyk S, Dougherty JrWG, Kassel WS, Zdilla MJ, Sieburth SM. Intramolecular Pyridone/Enyne Photocycloaddition: Partitioning of the $[4+4]$ and $[2+2]$ Pathways. Org Lett. 2011; 13: 2180-2183. (b). Sakuta $Y$, Kohari Y, Hutabarat NDMR, Uwai K, Kwon E, Okuyama Y, Seki C, Matsuyama H, Takano N, Tokiwa M, Takeshita M, Nakano H. Chiral Primary Amino Silyl Ether Organocatalyst for the Enantioselective DielsAlder Reaction of 1,2-Dihydropyridines with Aldehydes. Heterocycles. 2012; 86: 1379.

11. Tang $X$, Liu P, Li R, Jing Q, Lv J, Liu L, Liu Y. Milrinone for the Treatment of Acute Heart Failure After Acute Myocardial Infarction: A Systematic Review and MetaAnalysis. Basic Clin Pharmacol Toxicol. 2015; 117: 186-194.

12. Mizushige K, Ueda T, Yukiiri K, Suzuki H. Olprinone: A Phosphodiesterase III Inhibitorwith Positive Ino- 
tropic and Vasodilator Effects. Cardiovasc Drug Rev. 2002; 20:163-174.

13. (a). Fleming FF, Yao L, Ravikumar PC, Funk L, Shook BC. Nitrile-Containing Pharmaceuticals: Efficacious Roles of the Nitrile Pharmacophore. J. Med Chem. 2010; 53: 7902-7917.

14. Jochmans D, Deval J, Kesteleyn B, Marck HV, Bettens E, Baere ID, Dehertogh P, Ivens T, Ginderen MV, Schoubroeck BV, Ehteshami M, Wigerinck P, Gotte M, Hertogs KJ. Indolopyridones Inhibit Human Immunodeficiency Virus Reverse Transcriptase with a Novel Mechanism of Action. Virol. 2006; 80: 12283-12292.

15. Zulkepli NA, Rou KVK, Sulaiman WNHW, Salhin A, Saad B, Seeni A. A Synthetic Hydrazone Derivative Acts as an Apoptotic Inducer with Chemopreventive Activity on a Tongue Cancer Cell Line. Asian Pac J Cancer Prev. 2011; 12: 259.

16. Heravi MM, Hamidi H. Recent advances in synthesis of 2-pyridones: a key heterocycle is revisited . J. Iran Chem Soc. 2013; 10: 265-273.

17. Fier PS, Hartwig JF. Synthesis and Late-Stage Functionalization of Complex Molecules through $\mathrm{C}-\mathrm{H}$ Fluorination and Nucleophilic Aromatic Substitution. J Am Chem Soc. 2014; 136: 10139.

18. (a). Kim YH, Kim YJ, Chang SY, Kim BT, Heo JN. A General Strategy for the Synthesis of Amino-Substituted 2-Pyridones Using a Palladium-Catalyzed Amination Reaction. Bull Korean Chem Soc. 2007; 28: 777-782. (b). Fier PS, Hartwig JF. Selective C-H Fluorination of Pyridines and Diazines Inspired by a Classic Amination Reaction. Science. 2013; 342: 956-960.

19. Wang $D$, Zhao J, Wang $Y$, Hu J, Li L, Miao L, Feng H, Desaubry L, Yu P. A General and Efficient Synthesis of 2-Pyridones, 2-Quinolinones, and 1-Isoquinolinones from Azine N-Oxides. Asian J Org Chem. 2016; 5: 1442-1446.

20. Khan MN, Pal S, Parvin T, Choudhury LH. A simple and efficient method for the facile access of highly functionalized pyridines and their fluorescence property studies. RSC Adv. 2012; 2: 12305-12314.

21. (a). Reddy TRK, Mutter R, Heal W, Guo K, Gillet VJ, Pratt S, Chen B. Library Design, Synthesis, and Screening: Pyridine Dicarbonitriles as Potential Prion Disease Therapeutics. J Med Chem. 2006; 49: 607-615. (b). Singh KN, Singh SK. Microwave-assisted, one-pot multicomponent synthesis of highly substituted pyridines using KF/alumina. ARKIVOC. 2009; xiii: 153-160.

22. Jia R, Tu S, Zhang Y, Jiang B, Zhang J, Yao C, Shi F. An efficient and greener approach to the synthesis of 3,5dicyanopyridin-2(1H)-one derivatives in aqueous media under microwave irradiation conditions. J Heterocyclic Chem. 2007; 44: 1177-1180.

23. Zhu Y, Tong W, Gao C, Mohwald H. Fabrication of bovine serum albumin microcapsules by desolvation and destroyable cross-linking. J Mater Chem. 2008; 18: 1153-1158 